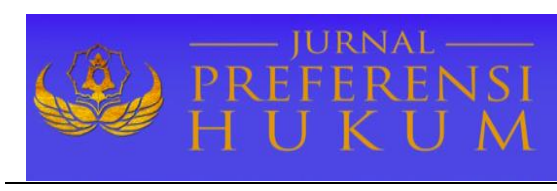

Jurnal Preferensi Hukum | ISSN: 2746-5039

Vol. 2, No. 1 -Februari 2021, Hal. 145-149| Available online at https://www.ejournal.warmadewa.ac.id/index.php/juprehum

DOI: https://doi.org/10.22225/jph.2.1.3060.145-149

\title{
PERLINDUNGAN HUKUM NASABAH KARTU KREDIT DALAM PERSPEKTIF UNDANG-UNDANG NOMOR 8 TAHUN 1999
}

\author{
Nyoman Triananda Prayoga, I Nyoman Sujana, Ni Made Puspasutari Ujianti \\ Fakultas Hukum Universitas Warmadewa, Denpasar-Bali, Indonesia
}

\begin{abstract}
Abstrak
Pada saat ini teknologi sudah berkembang dengan pesat, begitu pula dengan alat pembayaran. Salah satu perkembangan itu yakni Kartu kredit. Kartu kredit adalah kartu plastik yang diterbitkan oleh bank yang memberikan jasa kredit. Namun, banyak terjadi kasus pada kartu kredit yang sering terjadi seperti kehilangn atau penipuan online. Penelitian ini bertujuan untuk mengetahui bentuk perlindungan hukum bagi nasabah kartu kredit menurut Undang-Undang Perlindungan Konsumen dan untuk mengetahui akibat hukum bila kartu kredit digunakan oleh orang lain. Penelitian ini menggunakan metode penelitian normatif, adakah aturan hukum sesuai Norma Hukum dan adakah Norma yang berupa perintah atau larangan itu sesuai dengan prinsip hukum serta apakah tindakan seseorang sudah sesuai dengan Norma Hukum. Hasil penelitian menunjukan bahwa bentuk perlindungan hukum yang diberikan oleh pemerintah berupa peraturan perundang-undangan, namun peraturan perundang-undangan tersebut belum efektif. Akibat hukum apabila kartu kredit digunakan orang lain, nasabah pemilik kartu kredit tetap harus membayar tagihan yang masuk sampai nasabah melaporkan secara tertulis. Pemerintah seharusnya mengefektifkan Undang-Undang dan membuat undang-undang khusus tentang kartu kredit serta pihak bank dan nasabah harus saling terbuka.
\end{abstract}

Kata Kunci: Perlindungan Hukum, Nasabah, Kartu Kredit

\begin{abstract}
At this time technology has developed rapidly, as is the means of payment. One such development is the credit card. Credit cards are plastic cards issued by banks that provide credit services. However, there are many cases on credit cards that often occur such as loss or online fraud. This study aims to determine the form of legal protection for credit card customers according to the Consumer Protection Act and to find out the legal consequences if a credit card is used by someone else. This study uses a normative research method, are there legal rules according to legal norms and are there norms in the form of orders or prohibitions in accordance with legal principles and whether one's actions are in accordance with legal norms. The results showed that the form of legal protection provided by the government was in the form of statutory regulations, but these statutory regulations were not yet effective. The legal consequence is that if the credit card is used by someone else, the customer who owns the credit card still has to pay the incoming bill until the customer reports it in writing. The government should make effective laws and make specific laws regarding credit cards and banks and customers must be open to each other.
\end{abstract}

Keywords: Legal Protection, Customer, Credit Card

\section{PENDAHULUAN}

Perkembangan kehidupan manusia saat ini berkembang dengan sangat cepat diantaranya dalam dunia finansial, pemakaian kartu kredit atau kartu plastik dalam hal melakukan transaksi berkembang sangat pesat dan benar-benar diperlukan oleh masyarakat. Ini karena keuntungan dari penggunaan kartu kredit yang dianggap mempermudah dalam melakukan sistem pembayaran dan dalam hal konsumen tak perlu bawa uang banyak karena konsumen dapat menggunakan kartu kredit dalam berbelanja. Hal ini menjadi tren baru yang sangat diminati oleh kalangan masyarakat dikarenakan tuntutan zaman yang mengharuskan segala sesuatunya serba instant. Dahulu proses jual-beli dilakukan dengan cara penjual dan pembeli bertemu di suatu tempat serta melakukan transaksi secara langsung namun beda halnya dengan saat ini penjual dan pembeli dapat melakukan transaksi meskipun mereka tidak bertemu secara langsung.

Kartu kredit merupakan kartu berbahan plastik yang dikeluarkan oleh pihak bank atau pihak perusahaan pengelola kartu kredit, dengan memberikan hak kepada seseorang yang telah memenuhi persyaratan yang telah ditentukan sehingga nama pihak yang bersangkutan akan tertera pada kartu untuk dipergunakan sebagai alat pembayaran secara kredit atas perolean barang atau jasa, dan atau untuk menarik uang tunai dalam batas kredit sesuai yang telah ditentukan oleh pihak penerbit kartu 
kredit (Subekti, 2005). Perjanjian kartu kredit merupakan perjanjian yang dilakukan dengan tujuan menerbitkan kartu kredit yang akan dimanfaatkan oleh pemegang kartu untuk membayar barang atau jasa, perjanjian ini mengacu kepada perjanjian pinjam meminjam yang diatur dalam pasal 1754 KUHPerdata.

Terkait dengan isu perlindungan hukum nasabah, berikut ini beberapa penelitian telah mengkajinya sebelumnya, seperti Barkatullah \& Djumadi (2018); Begley \& Purnanandam (2021); Romeo \& Sandler (2021); Massoud, Saunders, \& Scholnick (2011); Gaganisa, Galariotis, Pasiouras, \& Staikouras (2020). Selama ini antara nasabah pemegang kartu kredit dan pihak bank sering ditemukan permasalahan yang berhubungan dengan pemakaian jasa electronic fundstransfer dan juga penyalahgunaan fungsi. Hal ini apabila dilihat dari hukum perdata dalam lingkup hukum perjanjian sebagai perbuatan wanprestasi bisa menyelesaikan dengan melihat pada perjanjian kedua sisi pihak, yakni yang tercantum dalam Undang-Undang Nomor 8 Tahun 1999 tentang Perlindungan Konsumen (selanjutnya disebut Undang-Undang Perlindungan Konsumen). Contohnya seperti kasus dimana kartu kredit nasabah hilang dan dipergunakan oleh orang lain yang tidak berhak menggunakannya. Berdasarkan latar belakang tersebut, penelitian ini bertujuan untuk mengkaji bentuk perlindungan hukum bagi nasabah kartu kredit menurut Undang-Undang Perlindungan Konsumen dan mengetahui akibat hukum bila kartu kredit digunakan oleh orang lain.

\section{METODE PENELITIAN}

Penelitian ini didesain dengan menggunakan metode penelitian hukum normative. Pendekatan masalah yang digunakan yakni pendekatan perundang-undangan dan pendekatan konseptual (Hadjon, 2005; Marzuki, 2011). Pendekatan perundang-undangan ditelaah secara baik dan peraturan perundang-undangan tersebut juga berhubungan dengan masalah yang ada, sedangkan pendekatan konseptual merupakan suatu pendekatan yang di dalam ilmu hukum ada dan berkembang pemikiran dan doktrin para sarjana.

Adapun sumber bahan hukum yang digunakan yang bersumber dari penelitian dan kepustakaan berupa (1) Bahan hukum primer yaitu bahan-bahan hukum berupa peraturan perundang-undangan yakni: UU No. 10/1998 tentang Perubahan atas UU No. 7/1998 tentang Perbankan, UU No. 8/1999 tentang Perlindungan Konsumen. (2) Bahan hukum sekunder yaitu bahan-bahan hukum yang diperoleh dari pengkajian kepustakaan (Library Research) yaitu dengan membaca buku-buku hukum, jurnal-jurnal hukum, surat kabar dan juga dari internet yang berkaitan dengan permasalahan yang di teliti.

Teknik pengumpulan bahan hukum yang digunakan dalam peneliti ini adalah teknik dokumentasi yang dilaksanakan sesuai cara menginventarisasi dan mengkategorisasi bahan-bahan hukum baik peraturan perundang-undangan, literatur-literatur maupun bahan hukum lainnya yang berkaitan terhadap perlindungan hukum nasabah kartu kredit dalam perspektif undang-undang nomor 8 tahun 1999. Selanjutnya dilakukan dengan metode pencatatan yaitu dengan cara mengutip, meringkas, dan memberikan ulasan-ulasan dengan topik bahasan. Setelah data terkumpul, kemudian, diolah dan dianalisis dengan menggunakan metode pengolahan bahan hukum secara sistematis yaitu, dengan menggunakan argumentasi hukum berdasarkan logika dedukatif dan indukatif serta penyajiannya dilakukan dengan cara deskriptif analisis, yaitu suatu cara analisis bahan hukum yang dilakukan dengan menyusun secara sistematis.

\section{HASIL DAN PEMBAHASAN}

\section{Bentuk Perlindungan Hukum bagi Nasabah Kartu Kredit Menurut Undang-Undang Perlindungan Konsumen}

Menurut Pasal 1 angka 2 UU Perlindungan Konsumen pengertian konsumen adalah orang pemakai barang dan jasa yang ada dalam masyarakat, baik untuk diri sendiri, keluarga, ataupun orang lain yang tidak untuk diperdagangkan. Namun sebelum diterbitkannya UU Perlindungan Konsumen pengertian mengenai konsumen tidak dicantumkan secara jelas dan mendetail.

Dalam perbankan konsumen disebut pula sebagai nasabah, menurut Komarudding nasabah merupakan orang atau suatau perusahaan yang memiliki rekening koran atau deposito ataupun tabungan yang sama lainnya pada sebuah bank (Komaruddin, 1994:5).

Di Indonesia perlindungan konsumen/ nasabah pada tahun 1998 telah mendapatkan perhatian lebih dari pemerintah terlihat dengan diterbitkannya UU Perlindungan Konsumen yakni UU Nomor 8 
Tahun 1999 tentang Perlindungan Konsumen. Hal ini memberikan rasa aman dan rasa terlindungi karena telah memiliki landasan dan payung hukum guna melindungi semua kegiatan-kegiatan yang terjadi dalam dunia usaha sehingga memudahkan pemerintah dan lembaga terkait dalam melakukan penataan, pembinaan serta pendidikan kepada konsumen sehingga memaksimalkan peran konsumen dalam dunia perdagangan, perbankan, dan lain sebagainya.

Nasabah dan bank membuat suatu perjanjian sebelum nasabah dapat menggunakan kartu kredit. Atas dasar perjanjian tersebut menghasilkan suatu hubungan hukum yang menimbulkan hak dan kewajiban antara para pihak. Hak dan kewajiban para pihak terkait dalam melindungi pemegang kartu kredit dengan ketentuan sebagai berikut:

1. Aturan hak dan kewajiban antara pihak pemegang, penerbit dan penjual yang seimbang.

2. Ketegasan hak dari masing-masing pihak agar dapat menggugat pihak lainnya

3. Kesempatan yang sama di antara pemegang atau calon pemegang kartu kredit untuk mendapat kartu kredit atau mendapat perlakuan sama, dalam arti penerbit dilarang membedakan perlakuan terhadap pemegang atau calon pemegang dengan alasan atau kriteria yang tidak reasonable

4. Kewajiban penerbit untuk melakukan disclousure terhadap pemegang tentang:

a. Besarnya bunga kredit dan cara menghitungnya

b. Seluruh fee yang dipungut, seperti annual fee, card issuance fee, transaction fee

c. Denda keterlambatan atau biaya untuk cash payment

d. Grace periode antara penagihan dan keharusan pembayaran

e. menghalangi penerbit mencegah penjual untuk melakukan discount jika dilakukan pembayaran harga barang secara cash

f. Memberi ketentuan bagi penjual untuk mengembalikan harga pembelian dengan kartu kredit apabila pengembalian barang karena salah penjual

g. Melarang penjual meminta kelebihan biaya apabila dengan kartu kredit

h. Jika ada protes dari pemegang terhadap tagihan, mewajibkan penerbit melakukan investigasi secepatnya dan melakukan koreksi secepatnya jika ada kesalahan dalam perhitungan pembayaran.

Kartu kredit ialah alat pembayaran menggunakan kartu yang bisa dipakai untuk melakukan pembayaran terhadap kewajiban dari kegiatan ekonomi, termasuk transaksi belanja atau guna melakukan tarik tunai dan pemegang kartu harus melakukan pembayaran lunas tagihan tersebut pada waktu yang disepakati baik dengan cara pembayaran penuh ataupun angsuran.

Bentuk perlindungan hukum yang diberi guna melindungi konsumen setelah terjadi konflik, yang membuat konsumen dirugikan. Sehingga konsumen bisa menuntut pelaku usaha melalui lembaga terkait (luar peradilan umum) yang dapat menyelesaikan permasalahan antar para pihak atau bisa melalui peradilan umum yang berada di lingkungan pradilan umum hal ini tercantum dalam Pasal 45 ayat (1) dan ayat (2) UU Perlindungan Konsumen.

\section{Akibat Hukum Bila Kartu Kredit Digunakan oleh Orang Lain}

Pemegang kartu merupakan pengguna sah dari PBI APMK yang dimanana hal ini diatur dalam Pasal 1 angka 7 Peraturan Bank Indonesia Nomor: 14/2/PBI/2012 tentang Perubahan Atas Peraturan Bank Indonesia Nomor 11/11/PBI/2009 Tentang Penyelenggaraan Kegiatan Alat Pembayaran Dengan Menggunakan Kartu ("PBI APMK"). Sehingga apabila kartu kredit pengguna hilang namun kartu kredit tersebut digunakan oleh orang lain dan nasabah merasa dirugikan karena tidak merasa menggunakan kartu kredit tersebut, namun pihak bank hanya mengethaui bahwa yang menggunakannya adalah nasabah yang namanya tertera pada kartu tersebut yang merupakan pengguna yang sah.

Konsumen atau nasabah juga memiliki kewajiban untuk menjaga kartu kredit tersebut agar tidak hilang dan berpidah tangan kepada orang lain, tidak hanya bank yang harus meningkatkan keamanan agar kartu kredit tersebut tidak disalahgunakan oleh orang lain. Akibat hukum apabila terjadi kehilangan kartu kredit dan kartu kredit tersebut telah digunakan oleh orang lain selama nasabah belum melapor kepada pihak bank terkait serta melampirkan surat kehilangan dari kepolisian, nasabah tetap harus membayar segala transaksi yang terjadi akibat penggunaan kartunya sampai pada tanggal diterima pemberitahuan tertulis mengenai kehilangan tersbut oleh bank. 
Kartu kredit juga dapat dilakukan oleh orang lain dengan melakukan perbuatan melawan hukum yang disebut dengan carding. Carding merupakan kejahatan yang dilakukan dengan menggunakan teknologi computer melalu jaringan internet untuk melakukan pembayaran dengan menggunakan kartu kredit orang lain sehingga menimbulkan kerugian yang bersifat materiil maupun non materiil.

Menurut, Suseno (2004:12), faktor penghambat yang menjadi kendala sehingga perlindunagn hukum bagi pemilik kartu kredit belum bisa dilakukan dengan seharusnya yakni:

1. Dari sisi pelaku usaha

Masalah yang ada dalam perlindungan kartu kredit dapat timbul dari pihak pelaku usaha itu, dimana pelaku usaha itu dapat melakukan kesalahan yang terjadi dalam transaksi kartu kredit nasabah, seperti pihak bank bertanggung jawab untuk memperoleh tanda buki penerimaan dari penerima uang, masalah transfer dana yang tidak sampai ke tangan nasabah kartu kredit.

2. Dari sisi nasabah sebagai konsumen

Hal ini terjadi karena kecerobohan nasabah selaku pemilik kartu kredit yang sah tidak membaca syarat dengan baik pada saat melakukan tanda tangan aplikasi kartu kredit tersebut.

3. Dari sisi lain (teknologi serta tanggung jawab orang terkait)

a. Kemungkinan terjadinya penyalahgunaan ektronik oleh orang tak bertanggung jawab.

b. Bila muncul masalah karena jasa elektronik tersebut, nasabah akan mengalami kesuliatn dalam melakukan klaim kepada pihak bank dikarenakan tak ada bukti atas transaksi yang dilakukan oleh pemilik kartu kredit.

c. Konsisi VSAT (Jaringan Vertikal Satelit) merupakan jaringan komunikasi yang seringkali menjadi hambatan, karena teknologi canggih tersebut belum dapat membuat rasa aman dan nyaman yang terbaik bagi nasabah.

d. SDM yang tidak terlalu mendukung.

e. Peran orang-orang yang terkait dianggap kurang berperan terhadap perlindungan bagi pemilik kartu kredit, seperti Bank Indonesia dalam pemberian perlindungan bagi nasabah masih ada batas dengan kegiatan operasional di bank. Sedangkan lembaga perlindungan konsumen juga belum melakukan peran dengan baik dalam pemberian perlindungan kepada konsumen. Kurangnya sosialisasi yang dilakukan oleh lembaga tersebut yang mengakibatkan nasabah tidak mengetahui keberadaan lembaga ini.

4. Dari Per-UUan

Selama ini tidak ada peraturan khusus mengenai kartu kredit di Indonesia untuk menjadi pedoman. Meski, saat ini pemerintah telah membuat UU No. 11 Tahun 2008 tentang Informasi dan Transaksi Elektronik, namun rasanya UU itu belum efisien, ini karena adanya kritik di UU tersebut. Kebijakan praturan mengatasi kejahatan yang muncul melalui kartu kredit tampaknya belum jelas. Dalam UU No. 11 Tahun 2008 tentang Informasi dan Transaksi Elektronik hanya ada satu pasal yang mengatur kejahatan kartu kredit, yaitu berhubungan dengan suatu perlakuan menggunakan kartu kredit orang lain secara melawan hukum. Atas dasar alur proses transaksi kartu kredit, ketentuan pada Pasal 51 UU No. 11 Tahun 2008 tentang Informasi dan Transaksi Elektronik hanya bisa mencakup pelanggaran di tahapan card embossing and delivery (courir/recipient or customer) dan usage.

\section{Simpulan Dan Saran \\ 1. Simpulan}

Penggunaan kartu kredit biasanya, antar pihak membuat perjanjian lebih dulu karena perjanjian tersebut memunculkan hubungan hukum berupa hak dan kewajiban antar pihak. Karena hal tersebut, maka perlu adanya perlindungan hukum dalam rangka melindungi pemilik kartu kredit. Bentuk perlindungan hukum yang diberikan berupa UU No. 10 Tahun 1998 tentang Perbankan dan UU No. 8 Tahun 1999 tentang Perlindungan Konsumen. Penyelesaian masalah yang ada dapat dilakukan melalui pengadilan atau diluar pengadilan. Kemudian, bila kartu kredit hilang dan digunakan oleh orang lain yang menemukan serta pemilik belum membuat laporan kehilangan kepada bank maka pemilik masih harus bertanggung jawab untuk membayar segala tagihan yang ada. Menurut KUHPidana akibat hukumnya adalah pidana penjara paling lama 5 tahun atau denda paling besar Rp. 900.000,00 (Sembilan ratus ribu rupiah) serta pidana penjara paling lama 4 tahun bila melakukan penipuan. 


\section{Saran}

Melalui penelitian ini diharapkan kepada pemerintah untuk membuat peraturan khusus tentang transaksi kartu kredit. Meskipun pemerintah sudah membuat undang-undang tentang informasi dan transaksi elektronik namun, undang-undang tersebut belum efisien. Kemudian, diharapkan kepada pemilik kartu kredit harus memiliki sikap proaktif untuk mencari tahu tentang hak dan kewajibannya. Pihak bank juga semestinya bersikap lebih terbuka. Sehingga hubungan antar keduanya akan berjalan baik.

\section{DAFTAR PUSTAKA}

Barkatullah, A. H., \& Djumadi. (2018). Does Self-regulation Provide Legal Protection and Security to Ecommerce Consumers? Electronic Commerce Research and Applications, 30, 94-101.

Begley, T. A., \& Purnanandam, A. (2021). Color and Credit: Race, Regulation, and the Quality of Financial Services. Journal of Financial Economics, 3(1), 1-22.

Gaganisa, C., Galariotis, E., Pasiouras, F., \& Staikouras, C. (2020). Bank Profit Efficiency and Financial Consumer Protection Policies. Journal of Business Research, 118, 98-116.

Hadjon, P. M. (2005). Pengantar Hukum Administrasi Indonesia. Yogyakarta: Universitas Gadjah Mada Press.

Komaruddin. (1994). Kamus Perbankan. Jakarta: CV. Rajawali.

Marzuki, P. M. (2011). Penelitian Hukum. Jakarta: Kencana Prenida Media.

Massoud, N., Saunders, A., \& Scholnick, B. (2011). The Cost of being Late? The Case of Credit Card Penalty Fees. Journal of Financial Stability, 7(2), 49-59.

Romeo, C., \& Sandler, R. (2021). The Effect of Debt Collection Laws on Access to Credit. Journal of Public Economics, 195(104320).

Subekti, R. (2005). Hukum Perjanjian. Jakarta: Intermasa.

Suseno, S. (2004). Kejahatan Kartu Kredit dalam RUU Informasi dan Transaksi Elektronik. Bandung: Universitas Katolik Parahyangan.

Undang-Undang Nomor 10 Tahun 1998 tentang Perbankan

Undang-Undang Nomor 8 Tahun 1999 Tentang Perlindungan Konsumen 